\title{
Effect of Work Safety and Work Healthy Towards Employee's Productivity in PT. Sisirau Aceh Tamiang
}

\author{
Zulkarnen Mora ${ }^{1}$, Agung Suharyanto ${ }^{2}$, M. Yahya ${ }^{3}$ \\ ${ }^{1}$ Management Study Program, Faculty of Economics, Universitas Samudra, Indonesia \\ ${ }^{2}$ Study Program of Public Administration, Faculty of Social and Political Sciences, Universitas Medan Area, \\ Indonesia. \\ ${ }^{3}$ Program Studi Manajemen Keuangan Syariah. Fakultas Ekonomi dan Bisnis Islam, Institut Agama Islam \\ Negeri Langsa, Indonesia \\ zulkarnen.mora@unsam.ac.id
}

\section{Abstract}

This study aims to determine the effect of work safety and work healthy on employee productivity in the production department at PT. Sisirau Aceh Tamiang. This research is a type of quantitative research with a sample of 45 people. The data analysis method used is multiple linear regression analysis. Hypothesis testing is done through $t$ test, $F$ test, and the coefficient of determination $(R 2)$. Regression equation results obtained $Y=2.255+0.314 X 1$ $+0.811 X 2$ means that the constant value of 2.255 is the value of employee productivity before being influenced by work safety and health. The work safety regression coefficient is 0.314 and is positive, meaning that if work safety is increased the employee's work productivity will increase by 0.314 with a tcount> ttable (2.333> 1.68195) and significant $(0.025<0.05)$. The work health regression coefficient is 0.118 and is positive, meaning that if work health is improved the employee's work productivity will increase by 0.811 with a tcount $>$ ttable $(8.063>1.68195)$ and significant $(0.000<0.05)$. The coefficient of determination (R2) of 0.614 or $61.4 \%$, which means the work safety and health variables influence the work productivity of employees by $61.4 \%$ and the remaining $39.6 \%$ is influenced by other variables not examined in this study.
Keywords

work safety; work healthy; work productivity

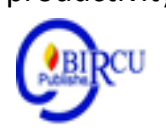

\section{Introduction}

Employees are one of the most important assets in the company, every employee is required to play an active role in setting plans, systems, processes, and goals to be achieved by the company. One way to achieve the effectiveness of a company is to foster and utilize human resources in order to produce a quality workforce, physically and mentally healthy, and have high skills to support the company's success. One important factor to consider is employee safety and health.

Work safety and health are activities that guarantee the creation of safe working conditions, avoiding physical and mental disruption at work that aims to reduce and avoid the risk of work accidents (zero accident). In working, employees have the right to work safety and health whose implementation is based on Law No. 13 of 2003 concerning manpower Article 86 paragraph (1) states that every worker / laborer has the right to obtain protection for: a) work safety and health, b) morals and decency, c) treatment in accordance with human dignity and religious values. Work safety is the protection of employees from injuries caused by work-related accidents. While work healthy is a condition that is free from physical, mental, emotional or pain disorders caused by the 
work environment. According to Kuswati (2019) Organizational effectiveness is usually interpreted as the success achieved by an organization in its efforts to achieve predetermined goals. Employees who have a high level of physical, mental and social health will be able to work with optimal deployment of personnel so that high performance can then increase productivity.

Employee performance is closely related to the results of one's work in an organization or company. The results of the work can involve quality, quantity, and timeliness, but performance evaluation in a company's organization is key in employee development. Performance evaluation is in principle a manifestation ofan employee's performance appraisal form (Irfansyah, 2020). According to Muhammad (2019) Performance is also called work performance, where the work of someone produces something that matches their ability.

Work safety is a safe or safe condition for sufferers, damage or loss at work. Safety risks are aspects of the work environment that can cause fires, bruises, sprains, fractures, impaired vision and hearing. Whereas work healthy shows a condition that is free from physical, mental emotional or pain disorders caused by the work environment. Health risks are factors in the work environment that work beyond the specified time period (Mangkunegara, 2009).

Based on data obtained from the employment of PT. Sisirau Aceh Tamiang, from 20152016 there have been 9 people who have experienced workplace accidents (can be seen in appendix IV). Work accident case at PT. Sisirau Aceh Tamiang is classified based on the parts / units of work that can be seen in table 1 below:

Table 1. Work Accident Report at PT. Sisirau Aceh Tamiang 2015-2016

\begin{tabular}{|c|l|c|c|}
\hline No & \multicolumn{1}{|c|}{ Work Section } & $\mathbf{2 0 1 5}$ & $\mathbf{2 0 1 6}$ \\
\hline 1. & Fruit reception and sorting station & 2 & 0 \\
\hline 2. & Boiling Station (sterilizer) & 1 & 1 \\
\hline 3. & Brondolan separation station (Thresing) & 0 & 0 \\
\hline 4. & Pressing station (Pressing) & 1 & 0 \\
\hline 5. & Purification station (Clarification) & 0 & 0 \\
\hline 6. & Seed processing station (Kernel) & 0 & 0 \\
\hline 7. & Machine parts (Engine room) & 0 & 0 \\
\hline 8. & Water treatment station & 2 & 1 \\
\hline 9. & Boiler / boiler station & 6 & 3 \\
\hline & Total & & 0 \\
\hline
\end{tabular}

Source: PT. Sisirau Aceh Tamiang (2017)

Table 1 above obtained from PT. Sisirau Aceh Tamiang, there are several cases of workplace accidents precisely occurred in 2015-2016. One of the dominant cases occurs in the boiler / boiler, such as: bursts of fire and bursts of hot water.

Table 2. Health Reports at PT. Sisirau Aceh Tamiang 2015-2016

\begin{tabular}{|c|l|c|c|}
\hline No & \multicolumn{1}{|c|}{ Type of disease } & $\mathbf{2 0 1 5}$ & $\mathbf{2 0 1 6}$ \\
\hline 1. & ISPA (Upper respiratory tract infections) & 3 & 5 \\
\hline 2. & THT (Ear, nose and throat) & 3 & 2 \\
\hline 3. & Burns & 2 & 1 \\
\hline 4. & Eyeaches & 1 & 2 \\
\hline \multicolumn{2}{|c|}{ Total } & 9 & 10 \\
\hline
\end{tabular}

Source: PT. Sisirau Aceh Tamiang (2017) 
In addition to data from staffing and company clinics, after a brief interview of 2 employees there is potential for pressure due to continuous noise that makes employees feel uncomfortable. Based on the noise test conducted by Medan work Safety and Health at PT. Sisirau Aceh Tamiang in 2015 showed that the factory boiler area and engine room had test results of 89.7-90.8 dB, respectively, according to Decree of the Minister of Manpower and Transmigration No. 13 of 2011 stating that the threshold value for noise was $85 \mathrm{~dB}$.

In general, work accidents are caused by human factors (unsafe action). Unsafe action is the wrong action at work and not in accordance with what has been determined (human error), usually occurs because of physical imbalances in the workforce and lack of education. Meanwhile, due to unfavorable work environment or dangerous working equipment condition (unsafe condition) which is usually influenced by things such as improper equipment, safety devices that do not meet the standards. These two things explain that human behavior is the main cause of accidents in the workplace.

In addition to humans as one of the main factors in work accident problems, the work environment also often does not help employees to optimize production processes and work productivity, room temperature that must be adjusted such as humidity levels and air conditions (ventilation), lighting which is the most important thing to do work is often overlooked which results in the emergence of eye fatigue and results in decreased levels of employee work efficiency. Therefore, the work environment is often filled with smoke and dust that can interfere with health, safety, and work productivity must be considered and adjusted to the conditions and work environment.

Due to the existence of several types of work activities that have a high enough risk in doing their jobs employees are required to use Personal Protective Equipment (PPE) such as safety shoes, masks, and gloves. But the reality is that employees often ignore the obligation to use PPE in the company, so that work accidents often occur such as a hand being scratched by a machine, blisters caused by sparks, and being pinched due to employee negligence (human error) which is spurred by a lack of average education. By each employee.

Productivity is a person's ability to use all his ability to realize creativity. Thus productivity is the relationship between the results (outputs) obtained with the resources used (inputs) to produce them. Work safety and health is one of the factors that affect employee work productivity, if the level of work safety is high then accidents that cause illness, disability, and death can be reduced as little as possible. And if work safety is low then this will adversely affect health so that it results in decreased work productivity (Latief, et.a ll, 2019). Hasibuan (2012) states that productivity is the ratio between output (output) and input (input). If productivity rises this is only possible by an increase in efficiency (time, materials, energy) with the work system, technical production and an increase in the skills of the workforce. Whereas Yuniarsih and Suwanto (2013) argue that productivity can be interpreted as a concrete result (product) produced by individuals or groups, during a certain unit of time in a work process. In this case, the higher the product produced in a shorter time it can be said that the level of productivity has a high value.

Yuniarsih and Suwatno (2013) states that the factors affecting productivity can be grouped into two, namely: 1) Internal Factors, consisting of: a) Strong commitment to institutional vision and mission. b) The structure and design of the work. c) Motivation, discipline, and work ethic that support the achievement of targets. d) Support resources that can be used to support the smooth implementation of tasks. e) Company policies that can stimulate (trigger) creativity and innovation. f) Pleasant treatment that can be given by the leadership and / or colleagues. g) Management practices adopted by the leadership. h) Ergonomic work environment. i) Conformity between the tasks carried by the educational background, experience, interests, expertise, and skills mastered. j) Communication between 
and between individuals in building cooperation. 2) External factors, consisting of: a) Legislation, government policy, and political situation. b) Partnerships (networking) developed. c) Culture and mindset of the environment around the organization. d) Overall community and stakeholder support. e) Level of competition. f) The impact of globalization.

But according to Sutrisno (2009) there are several factors that can affect employee work productivity, namely: 1) Training, work training is intended to equip employees with the right skills and ways to use work equipment. For this reason, job training is needed not only as a complement but as well as to provide the basics of knowledge. 2) Mental and physical abilities of employees, mental and physical state of employees is very important to be of concern to the organization, because the physical and mental state of employees has a very close relationship with employee productivity. 3) The relationship between superiors and subordinates, the relationship between superiors and subordinates will affect the activities carried out daily. How do superiors view subordinates, the extent to which subordinates are included in setting goals. Intertwining attitude has been able to increase employee productivity at work. Thus, if the employee is needed well, then the employee will participate well in the production process, so that it will affect the level of work productivity.

PT. Sisirau Aceh Tamiang is a private company engaged in the processing of palm oil (CPO) with a production capacity of 30 tons per hour. Especially in the production department, where in this section if an error occurs in operating control it can cause accidents, blasting, work diseases, environmental pollution or other operational disruptions.

A good company is a company that really takes care of the safety and health of its employees by making rules about work safety and health that are carried out by all employees and company leaders. Labor protection from hazards and illnesses caused by work or as a result of the work environment is needed by employees to feel safe and comfortable in completing their work. A healthy workforce will work productively, so employees are expected to increase work productivity and can support the company's business success. The aim of work safety and health is to guarantee the condition, wholeness and perfection, both physical and spiritual human beings and their cultural work aimed at the welfare of society in general and humans in particular (Sedarmayanti, 2007)

Opinion of Mangkunegara (2009) the purpose of work safety and health is a) so that every employee gets a guarantee of occupational safety and health physically, socially, and psychologically. b) So that every equipment and work equipment is used as well as possible, as effectively as possible. c) So that all products of production are kept safe. d) To guarantee the maintenance and improvement of employee nutritional health. e) To increase enthusiasm, work harmony, and work participation. f) To avoid health problems caused by the environment or working conditions. g) So that every employee feels safe and protected at work.

Factors causing occupational accidents, both in terms of occupational diseases and occupational accidents, are influenced by several factors (Sedarmayanti,2007), namely: a) Physical factors, including lighting, air temperature, humidity, air creed page, sound, mechanical vibration, radiation, air pressure, etc. b) Chemical factors, in the form of gas, steam, dust, fog, smoke, clouds, liquids, and solid objects. c) Biological factors, from animals and plants. d) Physiological factors, such as machine construction, attitude, and way of working. e) Psychological mental factors, including the composition of work, the relationship between employees or employers, work maintenance, and so on. 


\section{Research Methods}

This research was conducted to determine the effect of occupational safety and health on employee productivity at PT. Sisirau Aceh Tamiang having its address on the MedanBanda Aceh Vocational Youth road, Aceh Tamiang. The population in this study was employees of the production section at PT. Sisirau Aceh Tamiang, amounting to 45 people. While the sample selection in this study was carried out using the Nonprobability Sampling technique, which is a sampling technique that does not provide equal opportunity / opportunity for each element or member of the population to be selected as a sample. The sampling technique used in this study is the saturation sampling technique. Saturated sampling is a sampling technique when all members of the population are used as samples. Therefore, the number of samples used in this study was 45 people.

The data source in this study is primary data obtained by conducting research directly on the research object at PT. Sisirau Aceh Tamiang, which is done through observation, interviews, and distribution of questionnaires to respondents or employees of the production section at PT. Sisirau Aceh Tamiang. Observation, the researcher makes direct observations, especially on the work safety and health of employees at PT. Sisirau Aceh Tamiang. Interview is a method of data collection by conducting direct interviews with KTU, K3 employees and 2 employees of PT. Sisirau Aceh Tamiang to obtain the required information. And questionnaires are data collection techniques through questionnaires submitted to respondents. To obtain numerical data from the questionnaire the questionnaire answers were entered into a Likert scale of scores 1-5.

The data analysis method is done by multiple linear regression analysis formulated as $\mathrm{Y}$ $=a+b_{1} X_{1}+b_{2} X_{2}$ where $Y$ is work productivity, $X_{1}$ is work safety and $X_{2}$ is work health. And to test the hypothesis, several tests are carried out, namely: a) Partial Significant Test ( $t$ test), this test is carried out to find out how far the influence of one independent variable partially (individually) explains the dependent variable. The criteria for decision making are Ho is accepted if $t_{\text {count }}\left\langle t_{\text {table }}\right.$ at $(\alpha)=5 \%$ and $\mathrm{Ha}$ is accepted if $t_{\text {count }}>t_{\text {table }}$ at $(\alpha)=5 \%$. 2) Simultaneous Significant Test ( $F$ test), this test is carried out to see all the independent variables entered in the model have a simultaneous effect on the dependent variable. Where the decision making criteria is that Ho is accepted if $t_{\text {count }}<t_{\text {table }}$ at $(\alpha)=5 \%$ and $\mathrm{Ha}$ is accepted if $t_{\text {count }}>t_{\text {count }}$ at $(\alpha)=5 \%$. 3) Coefficient of Determination $\left(R^{2}\right)$, the coefficient of determination $\left(\mathrm{R}^{2}\right)$ basically measures how the model's ability to explain the effect of independent variables on the dependent variable where, $0 \leq \mathrm{R}^{2} \geq 1$. If $\mathrm{R}^{2}$ is greater (close to one), then it can be said that the influence of variables free is large towards the dependent variable. Conversely, if $\mathrm{R}^{2}$ gets smaller (near zero), it can be said that the effect of the independent variable is small on the dependent variable.

\section{Discussion}

Based on the results of the distribution of questionnaires to respondents by submitting several statements, the results obtained on the variable work safety: respondents' responses regarding "Work Safety" in the production section at PT. Sisirau Aceh Tamiang is as follows: respondent's response to the statement "The company provides work protective equipment such as heln, boots, gloves, and masks in accordance with work safety standards" in the category of disagreeing as much as 1 respondent with a percentage of $2.2 \%$, which stated agree as much as 26 respondents with a percentage of $67.8 \%$, who stated strongly agree as many as 18 respondents with a percentage of $40 \%$. Thus the highest respondent is agreed. The second statement "All work equipment is in good and proper condition" in the category of disagreement is 1 respondent with a percentage of $2.2 \%$, who states agree as many as 22 
respondents with a percentage of $48.9 \%$, and who states strongly agrees as many as 22 respondents with a percentage of $489 \%$. Thus the highest respondent is agreed and strongly agreed. The third statement "All parts of hazardous equipment have been given a warning sign" in the category of agree as many as 22 respondents with a percentage of $48.9 \%$ and who strongly agree as many as 23 respondents with a percentage of $51.1 \%$. Thus the highest respondent is very agreeing. The fourth statement "Every employee who works in a safe working environment" in the category of disagreement is 2 respondents with a percentage of $4.4 \%$, who states agree as many as 22 respondents with a percentage of $48.9 \%$, and who states strongly agree as many as 21 respondents with the percentage of $46.7 \%$. Thus the highest respondent is agreed. The fifth statement "The company conducts more intensive supervision of the implementation of your work" in the category of agreeing to 10 respondents with a percentage of $22.2 \%$, and which states strongly agree as many as 35 respondents with a percentage of $77.8 \%$. Thus the highest respondent is very agreeing. The sixth statement "The company provides a guarantee of safety insurance at work" in the category of agree as many as 10 respondents with a percentage of $22.2 \%$, and who stated strongly agree as many as 35 respondents with a percentage of $77.8 \%$. Thus the highest respondent is very agreeing.

Work health variables obtained responses to the statement "The environment in which you work has adequate air ventilation and lighting". In the category of disagreeing as much as 1 respondent with a percentage of $2.2 \%$, who stated agree as much as 27 respondents with a percentage of $60 \%$, and who stated strongly agree as much as 17 respondents with a percentage of $37.8 \%$. Thus the highest respondent is agreed. The second statement "The Company provides health insurance to every employee" in the category of agreed as many as 28 respondents with a percentage of $62.2 \%$, and which states strongly agree 17 respondents with a percentage of $37.8 \%$. Thus the highest responder is agreed. The third statement "The company provides drugs for first aid in the event of a work accident" in the category of disagreeing as much as 1 respondent with a percentage of $2.2 \%$, which states disagreeing as many as 12 respondents with a percentage of $26.7 \%$, which states agree as much as 27 respondents with a percentage of $60 \%$, and who states strongly agree as much as $5 \%$ with a percentage of $11.1 \%$. Thus the highest respondent is agreed. The fourth statement "Every sick employee will be referred to a hospital that has been determined by the company" in the category of agreed as many as 29 respondents with a percentage of $64.4 \%$, and who stated strongly agree as many as 16 respondents with a percentage of $35.6 \%$.

Thus the highest respondent is agreed. The fifth statement "The time given to carry out work is in accordance with the time set by the company" in the category of disagreement as many as 2 respondents with a percentage of $4.4 \%$, who agreed as much as 36 respondents with a percentage of $80 \%$, and who stated strongly agreed as much as 7 respondents with a percentage of $15.6 \%$. Thus the highest respondent is agreed. The sixth statement "The environment where you work in a clean condition so that it has a good influence on the continuity of employee work" in the category of disagreeing as much as 1 respondent with a percentage of $2.2 \%$, which states less agree as much as 7 respondents with a percentage of $15.6 \%$, who agree as many as 28 respondents with a percentage of $62.2 \%$, and those who stated strongly agree as many as 9 respondents with a percentage of $20 \%$. Thus the highest respondent is agreed.

And work productivity variable obtained response statement "I am able to carry out all the work in accordance with the capabilities that I have" in the category of not agree as much as 1 respondent with a percentage of $2.2 \%$, which states agree as many as 29 respondents with a percentage of $64.4 \%$, and which states strongly agree as many as 15 respondents with a percentage of $33.3 \%$. Thus the highest respondent is agreed. The second statement "The work that I endeavored to increase work productivity" in the category of agree as much as 32 
respondents with a percentage of $71.1 \%$, and who stated strongly agree as many as 13 respondents with a percentage of $28.9 \%$. Thus the highest respondent is agreed. The third statement "I was able to complete the job according to the schedule set" in the category of disagreeing as much as 1 respondent with a percentage of $2.2 \%$, which stated less agree as much as 2 respondents with a percentage of $4.4 \%$, who agreed as much as 29 respondents with a percentage of $64,4 \%$, and those who strongly agreed were 13 respondents with a percentage of $28.9 \%$. Thus the highest respondent is agreed. The fourth statement "To achieve the right work, I do not hesitate to ask back to the boss if the order given is unclear" in the category of agreeing to 31 respondents with a percentage of $68.9 \%$, and who stated strongly agree as many as 14 respondents with a percentage of $31,1 \%$ Thus the highest respondent is agreed. The fifth statement "The company provides job training to improve employee work ethic" in the category of disagreeing by 2 respondents with a percentage of $4.4 \%$, which states less agree as many as 11 respondents with a percentage of $24.4 \%$, who states agree as much as 25 respondents with a percentage of 55,6\%, and those who strongly agreed were 7 respondents with a percentage of $15.6 \%$. Thus the highest respondent is agreed. The sixth statement "In completing work, I am very concerned about the quality or the quality of the work produced" in the category of agree as many as 32 respondents with a percentage of $71.1 \%$, and those who stated strongly agree as many as 13 respondents with a percentage of $28.9 \%$. Thus the highest respondent is agreed.

Based on the results of regression analysis with the help of SPSS software Y results obtained are $2.255+0.314 \mathrm{X}_{1}+0.811 \mathrm{X}_{2}$. This regression model can be explained that the value of $\beta$ o which means a constant number of 2.225 shows that without the factors of occupational safety and occupational health, the score for employee productivity is 2.225. The $\beta_{1}$ value of 0.314 shows the meaning that if there is a change in the dimensions of work safety $\left(\mathrm{X}_{1}\right)$, the employee's work productivity $(\mathrm{Y})$ will experience a positive increase of 0.314 . A $\beta 2$ value of 0.811 shows the meaning that if there is a change in the dimensions of occupational health $\left(\mathrm{X}_{2}\right)$ then employee work productivity $(\mathrm{Y})$ will experience a positive increase of 0.811 . And the coefficient of determination of 0.614 or $61.4 \%$. This shows that the variable of work productivity $(\mathrm{Y})$ is influenced by the variables of occupational safety $\left(\mathrm{X}_{1}\right)$ and occupational health $\left(\mathrm{X}_{2}\right)$ of 0.614 or $61.4 \%$. While the remaining 0.396 or $39.6 \%$ is influenced by other variables outside this research model.

For the partial test, it was obtained that the $t_{\text {count }}$ for the work safety variable was 2.333 while the $t_{\text {table }}$ was 1.68195 then the $t_{\text {count }}$ was $2.333>t_{\text {table }} 1.68195$ with a significant level $(0.025<0.05)$ meaning that the work safety variable $(\mathrm{X} 1)$ had a positive effect and significant effect on employee productivity (Y). And the value of $t_{\text {count }}$ for occupational health variables is 8.063 while the value of $t_{\text {table }}$ is 1.68195 then the $t_{\text {count }}$ is $8.063>1.68195$ with a significant level $(0,000<0.05)$ meaning the occupational health variable $\left(\mathrm{X}_{2}\right)$ has a positive and significant effect on work productivity (Y) employee. As well as the simultaneous test results obtained that indicated $\mathrm{F}_{\text {count }}$ of 33.444 while $\mathrm{F}_{\text {table }}$ with a significance level of 0.05 amounted to 3.22 then $\mathrm{F}_{\text {count }}>$ Ftable (33.444> 3.22) with a significant level of $0.000<0.05$ so it can be concluded that the work safety variable and work health simultaneously (together) have a positive and significant effect on employee work productivity in the production department at PT. Sisirau Aceh Tamiang.

\section{Conclusion}

Based on the results of the analysis and discussion that has been carried out, it can be concluded that from the results of the multiple linear regression analysis test that the level of work safety has a positive effect on employee productivity, the results show that the regression coefficient for work safety $\left(\mathrm{X}_{1}\right)$ is 0.314 . Mean work productivity (Y) at PT. 
Sisirau Aceh Tamiang will increase by 0.314 if the effort to increase work safety goes up by one unit. And from the results of multiple linearregression analysis test that the level of occupational health there is a positive influence on employee productivity, the results show that the regression coefficient for work health $\left(\mathrm{X}_{2}\right)$ of 0.811 . Mean work productivity $(\mathrm{Y})$ at PT. Sisirau Aceh Tamiang will increase by 0.811 if the efforts to improve work health go up by one unit.

\section{References}

Arikunto, Suharsimi. (2010). Prosedur Penelitian: Suatu Pendekatan Praktik, revision edition, Jakarta: Rineka Cipta.

Bangun, Wilson. (2012). Manajemen Sumber Daya Manusia. Jakarta: PT. Gelora Aksara Pratama.

Hasibuan, Malayu S.P, (2012), Manajemen Sumber Daya Manusia, cetakan keenam belas, Jakarta: PT. Bumi Aksara.

Irfansyah. (2020). The Duties and Functions Performance of Aceh Human Resources Improvement Institutions inScholarship Study Program Implementation in Aceh Government. Britain International of Humanities and Social Sciences Journal: 160165.

Keputusan Menteri Tenaga Kerja No. 13 Tahun 2011 tentang NAB (Nilai Ambang Batas).

Kuswati, Y. (2019). Motivation Role in Improving Work Effectiveness. Budapest International Research and Critics Institute (BIRCI-Journal) : Humanities and Social Sciences, 2(4); 281-288.

Latief, A. Nurhalina. Medagri, E. \& Suharyanto, A. (2019). Pengaruh Manajemen Pengetahuan, Keterampilan dan Sikap terhadap Kinerja Karyawan. JUPIIS: Jurnal Pendidikan Ilmu-ilmu Sosial, 11 (2): 173-182.

Mangkunegara, Anwar Prabu, (2009), Manajemen Sumber Daya Manusia Perusahaan, Bandung: PT. Remaja Rosdakarya.

Mondy, R. Wayne. (2008). Manajemen Sumber Daya Manusia, edisi kesepuluh. Jakarta: Erlangga.

Muhammad and Hidayat, R. (2019). The Relationship between the Transformational Leadership Style of Madrasah Head and Work Discipline with the Performance of Teachers atMTsN Lima Puluh Batu Bara. Britain International of Linguistics, Arts and EducationSciences (BIoLAE) Journal, 175-182.

Sedarmayanti. (2007). Manajemen Sumber Daya Manusia Reformasi Birokrasi Dan Manajemen Pegawai Negeri Sipil. Bandung: PT. Refika Aditama.

Sugiyono. (2011). Statistik untuk Penelitian. Bandung: Alfabeta.

Sutrisno, Edy. (2009). Manajemen Sumber Daya Manusia, edisi pertama. Jakarta: Kencana Prenada Media Group.

Yuniarsih, Tjutju dan Suwatno. (2013). Manajemen Sumber Daya Manusia, cetakan keempat. Bandung: Alfabeta. 